\title{
PENGARUH KONSUMSI JANTUNG PISANG BATU TERHADAP PRODUKSI AIR SUSU IBU PADA IBU POST PARTUM DI DESA BANYUTOWO
}

\author{
Ajeng Maharani Pratiwi ${ }^{1}$, Sherly Fatikasari ${ }^{2}$, Erinda Nur Pratiwi ${ }^{3}$ \\ ${ }^{1}$ Universitas Kusuma Husada Surakarta \\ ${ }^{2}$ Sekolah Tinggi Ilmu Kesehatan Karya Husada Semarang \\ ${ }^{3}$ Universitas Kusuma Husada Surakarta \\ (ajengpratiwi937@gmail.com)
}

\begin{abstract}
ABSTRAK
Latar Belakang : Air susu ibu (ASI) adalah makanan terbaik untuk bayi. ASI sangat dibutuhkan untuk kesehatan bayi dan mendukung pertumbuhan dan perkembangan bayi secara optimal. Bayi yang mendapatkan ASI eksklusif akan memperoleh semua kelebihan ASI serta terpenuhi kebutuhan gizinya secara maksimal sehingga dia akan lebih sehat, lebih tahan terhadap infeksi, dan rentan alergi. Tujuan : Untuk mengetahui Pengaruh Konsumsi Jantung Pisang Batu Terhadap Produksi Air Susu Ibu pada Ibu Post Partum di Desa Banyutowo. Metode : Desain penelitian ini menggunakan metode Quasy Experiment dengan rancangan one grup pretest-posttest. Teknik sampling menggunakan purposive sampling, Jumlah responden 14. Hasil Penelitian : Produksi Asi sebelum konsumsi jantung pisang batu mempunyai rata rata 37.172, sedangkan setelah konsumsi jantung pisang batu mempunyai rata rata 59.556. Jadi ada perbedaan terhadap produksi ASI sebelum dan sesudah mengkonsumsi Jantung pisang batu.
\end{abstract}

Kata kunci : Produksi ASI, jantung pisang batu, post partum

\section{ABSTRACT}

Background: Breast milk is the best food for babies. Breast milk is needed for the health of the baby and supports optimal growth and development of the baby. Babies who are exclusively breastfed will get all the excess breast milk and have their nutritional needs met maximally so that they will be healthier, more resistant to infection, and prone to allergies. Objective: To determine the effect of the consumption of stone banana heart on the production of breast milk in postpartum mothers in the village of Banyutowo. Methods: The design of this study used the Quasy Experiment method with one group pretest-posttest design. The sampling technique used purposive sampling, the number of respondents was 14. Results: The production of breast milk before consumption of banana heart stones had an average of 37,172, while after consumption of banana heart had an average of 59,556. So there are differences in the production of breast milk before and after consuming the banana stone heart.

Keywords : Breastmilk production, stone banana heart, post partum

\section{PENDAHULUAN}

Air susu ibu (ASI) adalah makanan terbaik untuk bayi. ASI sangat dibutuhkan untuk kesehatan bayi dan mendukung pertumbuhan dan perkembangan bayi secara optimal. Bayi yang mendapatkan ASI eksklusif akan memperoleh semua kelebihan ASI serta terpenuhi kebutuhan gizinya secara maksimal sehingga dia akan 
lebih sehat, lebih tahan terhadap infeksi, tidak mudah terkena alergi, dan lebih jarang sakit (Sulistyoningsih, 2011).

World Health Organization (WHO) dan United Nations Childrens Fund (UNICEF) merekomendasikan agar ibu menyusui bayinya saat satu jam pertama setelah melahirkan dan melanjutkan hingga usia 6 bulan pertama kehidupan bayi. Pengenalan makanan pelengkap dengan nutrisi yang memadai dan aman diberikan saat bayi memasuki usia 6 bulan dengan terus menyusui sampai 2 tahun atau lebih (WHO, 2015). Pemberian ASI di Indonesia terkait ASI diduga masih minim, akibatnya berdasarkan Riset Kesehatan Dasar (Riskesdas) 2014, angka cakupan ASI di Indonesia hanya 42 persen. Angka ini jelas di bawah target WHO yang mengharuskan cakupan ASI minimal 50 persen (Kemenkes 2013).

Cakupan pemberian ASI eksklusif di Jawa Tengah tahun 2016 hanya sekitar 25,6\%. Angka tersebut lebih rendah dibandingkan pada tahun 2013 yakni sebesar 45,18\%. Dinas Kesehatan tingkat I Propinsi Jawa Tengah 2018 untuk deteksi tumbuh kembang balita di Jawa Tengah ditetapkan $81 \%$ tetapi cakupan diperiksa 40-59\% dan mengalami perkembangan tidak optimal sebanyak $0,14 \%$ (Dinas Kesehatan Kabupaten Pati, 2016). Berdasarkan data Dinas Kesehatan Kabupaten Pati, cakupan ASI eksklusif pada tahun 2015 sebesar 51,30\%,pada tahun 2017 sebesar 76.8\%, dan pada tahun 2018 sebesar 76,5\%.Target pencapaian pemberian ASI eksklusif nasional sekitar 80\%, sedangkan target pencapaian pemberian ASI eksklusif di Jawa Tengah sekitar 55\% (Walyani dkk, 2015)

Jantung pisang merupakan jenis tanaman yang mengandung laktagogum memiliki potensi dalam menstimulasi hormon oksitosin dan prolaktin seperti alkaloid, polifenol, steroid, flavonoid dan substansi lainnya paling efektif dalam meningkatkan dan memperlancar produksi ASI. Reflek prolaktin secara hormonal untuk memproduksi ASI, sewaktu bayi menghisap putting payudara ibu, maka akan terjadi rangsangan neurohormonal pada putting susu dan areola ibu. Rangsangan ini akan diteruskan ke hipofisis melalui nervos vagus, kemudian ke lobus anterio. Dari lobus ini akan mengeluarkan hormon prolaktin dan masuk ke peredaran darah dan sampai pada kelenjar-kelenjar pembuat ASI. 
Kelenjar ini akan terangsang untuk menghasilkan ASI (Astawam, 2015).

Berdasarkan studi pendahuluan yang sudah dilakukan di Desa Banyutowo yang dilakukan pada bulan November 2020, 10 orang ibu menyusui di Desa Banyutowo 70\% ibu menyusui menyatakan kalau produksi ASI nya kurang lancar karena ini adalah pengalaman menyusui untuk pertama kalinya. Sedangkan $30 \%$ ibu menyusui juga menyatakan ASInya kurang sehingga bayinya sering rewel, untuk mengatasinya ibu menyusui tersebut mengkonsumsi vitamin.

Berdasarkan latar belakang tersebut diatas, maka peneliti tertarik untuk melakukan penelitian tentang "Pengaruh Konsumsi Jantung Pisang Batu Terhadap Produksi Air Susu Ibu pada Ibu Post Partum di Desa Banyutowo"

\section{BAHAN DAN METODE}

Desain penelitian ini menggunakan metode Quasy Experiment dengan rancangan one grup pretest-posttest. Teknik sampling menggunakan purposive sampling, Jumlah responden 14. Instrumen yang digunakan dalam penelitian ini adalah :

a. SOP pembuatan jantung pisang batu b. SOP pemberian jantung pisang batu

c. Lembar observasi frekuensi dan durasi menyusui.

Data yang digunakan adalah data primer dan sekunder. Sebelum melakukan uji bivariat maka peneliti melakukan uji normalitas terlebih dahulu menggunakan uji Shapiro-Wilk test (bila sampel kurang dari 50 responden). Penelitian ini menggunakan uji Shapiro-Wilk test untuk mengetahui jumlah data yang normal atau tidak normal.

\section{HASIL}

1. Produksi Air Susu Ibu sebelum Konsumsi Jantung Pisang Batu

Tabel 1.Rerata Produksi Air Susu Ibu sebelum Konsumsi Jantung Pisang Batu pada Ibu Post Partum di Desa Banyutowo Tahun 2021

\begin{tabular}{|l|c|c|c|}
\hline $\begin{array}{l}\text { Produksi } \\
\text { ASI }\end{array}$ & $\mathrm{N}$ & Mean \pm SD & $\begin{array}{l}\text { Min- } \\
\text { Max }\end{array}$ \\
\hline Sebelum & 16 & $37.17 \pm 4.20$ & $30-45$ \\
\hline
\end{tabular}

Sumber data primer : 2021

Berdasarkan tabel $1 \mathrm{di}$ atas maka dapat diketahui bahwa produksi ASI sebelum Konsumsi Jantung Pisang Batu mempunyai mean 37.17, std.deviasi 4.20, dan produksi ASI terendah 30 tertinggi 45 . 
2. Produksi Air Susu Ibu sesudah

Konsumsi Jantung Pisang Batu

Tabel 2. Rerata ProduksiAir

Susu Ibu sesudah Konsumsi Jantung Pisang Batu pada Ibu Post Partum di Desa Banyutowo Tahun 2021

\begin{tabular}{|l|c|c|c|}
\hline $\begin{array}{l}\text { Produksi } \\
\text { ASI }\end{array}$ & N & Mean \pm SD & Min-Max \\
\hline Sesudah & 16 & $59.55 \pm 10.49$ & $41.25-75.83$ \\
\hline
\end{tabular}

Sumber : Data primer 2021

Berdasarkan tabel 2 di atas maka dapat diketahui bahwa produksi ASI pada ibu post partum sesudah Konsumsi Jantung Pisang Batu mempunyai mean 59,55, std.deviasi 10.49 dan produksi ASI terendah 41,25 tertinggi 75,83

3. Pengaruh Konsumsi Jantung Pisang Batu Terhadap Produksi Air Susu Ibu pada Ibu Post Partum di Desa Banyutowo Hasil uji normalitas menunjukkan sebelum diberikan Jantung Pisang Batu dengan nilai p-value 0.288 dan sesudah $0,473>$ 0,05 sehingga data disimpulkan terdistribusi normal sehingga menggunakan uji korelasi Paired Samples Test dengan hasil sebagai berikut :
Tabel 3.Analisa Pengaruh

Konsumsi Jantung Pisang Batu

Terhadap Produksi Air Susu Ibu pada Ibu Post Partum di Desa Banyutowo

\begin{tabular}{|c|c|c|c|}
\hline & $\mathrm{N}$ & Mean & P Value \\
\hline $\begin{array}{l}\text {-Produksi } \\
\text { Air Susu } \\
\text { Ibu } \\
\text { sebelum } \\
\text { Konsumsi } \\
\text { Jantung } \\
\text { Pisang } \\
\text { Batu } \\
\text { - Produksi } \\
\text { Air Susu } \\
\text { Ibu } \\
\text { sesudah } \\
\text { Konsumsi } \\
\text { Jantung } \\
\text { Pisang } \\
\text { Batu }\end{array}$ & 16 & 59.55 & 0,000 \\
\hline
\end{tabular}

Sumber : Data primer 2021

Berdasarkan analisa bivariat dengan menggunakan uji korelasi Paired Samples Test maka didapatkan hasil $\mathrm{p}$ value sebesar $0,000<0,05$ maka Ha diterima, ada Pengaruh Konsumsi Jantung Pisang Batu Terhadap Produksi Air Susu Ibu pada Ibu Post Partum di Desa Banyutowo

\section{PEMBAHASAN}

1. Produksi Air Susu Ibu Sebelum Konsumsi Jantung Pisang Batu Berdasarkan hasil penelitian terhadap 16 responden maka dapat diketahui bahwa produksi 
ASI sebelum Konsumsi Jantung

Pisang Batu di Desa Banyutowo mempunyai mean 37.17 , std.deviasi 4.20, dan produksi

ASI terendah 30 tertinggi 45 .

Hasil penelitian diatas menunjukkan bahwa produksi ASI setiap responden berbeda beda dengan teori yang menjelaskan kelancaran produksi ASI dipengaruhi oleh banyak faktor seperti, frekuensi pemberian ASI, berat bayi saat lahir, usia kehamilan saat bayi lahir, usia ibu dan paritas, stres dan penyakit akut, Inisiasi Menurut Mohanis mengatakan bahwa memberikan ASI eksklusif kepada bayi sangat menguntungkan untuk tumbuh kembang bayi. Prilaku ibi-ibu memberikan ASI eksklusif pada bayinya dipengaruhi oleh beberapa faktor diantaranya faktor pengetahuan, pendidikan, sikap, pekerjaan, ketersediaan waktu, dorongan keluarga, dan faktor dari petugas kesehatan (Kamariyah, 2014).

Sayur- sayuran tersebut terbukti mampu meningkatkan volume air susu ibu. Selain sayur-sayur tersebut, buah- buahan yang mengandung banyak air akan membantu ibu menghasilkan ASI yang berlimpah, seperti melon, semangka, pear, dan banyak lagi buah- buahan berair lain yang sangat baik dikonsumsi ibu menyusui (Fattah, 2016).

2. Produksi Air Susu Ibu Sesudah Konsumsi Jantung Pisang Batu Berdasarkan hasil penelitian sesudah Konsumsi Jantung Pisang Batu maka diketahui bahwa produksi ASI mempunyai mean 59,55, std.deviasi 10.49 dan produksi ASI terendah 41,25 tertinggi 75,83 .

Olahan jantung pisang dalam bentuk kuah bening dengan jumlah 200 gram yang diberikan selama satu minggu dan dikonsumsi dua kali sehari. Produksi ASI pada ibu nifas yang menyusui sebelum konsumsi jantung pisang ratarata $100 \%$ tidak lancar, setelah konsumsi jantung pisang produksi ASI $90 \%$ menjadi meningkat dan lancar dan $10 \%$ produksi ASInya tetap tidak lancar, responden mengatakan bahwa bayinya terlihat puas 
setelah menyusu dan tertidur.

Hasil penelitian ini didukung oleh Elly Wahyuni intesitas rata-rata frekuensi ASI sebelum konsumsi jantung pisang batu adalah 5,7 kali, setelah mengkonsumsi jantung pisang mengalami peningkatan menjadi 9,75 kali (Murtiana, 2011).

Hasil penelitian sejalan dengan teori Lingga dalam Murtiana), yang menyatakan bahwa jantung pisang batu memiliki beberapa senyawa yang dapat meningkatkan produksi dan kualitas ASI. Peningkatan produksi ASI dipengaruhi oleh adanya polifenol dan steroid yang mempengaruhi reflek prolaktin untuk merangsang alveoli yang bekerja aktif dalam pembentukan ASI. Hasil penelitian ini juga menyatakan bahwa peningkatan produksi ASI juga dirangsang oleh hormon oksitosin. Peningkatan hormon oksitosin dipengaruhi oleh polifenol yang ada pada jantung pisang batu yang akan membuat ASI mengalir lebih deras dibandingkan dengan sebelum mengkonsumsi jantung pisang batu. Oksitosin

merupakan hormon yang berperan untuk mendorong sekresi air susu (milk let down). Peran oksitosin pada kelenjar susu adalah mendorong kontraksi sel-sel miopitel yang mengelilingi alveolus dari kelenjar susu, sehingga dengan berkontraksinya sel-sel miopitel isi dari alveolus akan terdorong keluar menuju saluran susu, sehingga alveolus menjadi kosong dan memacu untuk sintesis air susu berikutnya (Harismayanti,2018).

3. Pengaruh Konsumsi Jantung Pisang Batu Terhadap Produksi Air Susu Ibu pada Ibu Post Partum di Desa Banyutowo

Berdasarkan analisa bivariat dengan menggunakan uji korelasi Paired Samples Test maka didapatkan hasil $\mathrm{p}$ value sebesar $0,000<0,05$ maka Ha diterima, ada Pengaruh Konsumsi Jantung Pisang Batu Terhadap Produksi Air Susu Ibu pada Ibu Post Partum di Desa Banyutowo.

Secara teknis kelancaran ASI dipengaruhi oleh makanan, salah satunya 
adalah jantung pisang yang bermanfaat

untuk

meningkatkan produksi ASI

pada ibu nifas karena jantung pisang mengandung laktogogum yang berfungsi untuk merangsang hormon oksitosin untk pengeluaran ASI. Jantung pisang memiliki khasiat yang sangat baik bagi kesehatan, kandungan zat gizi yang bermanfaat bagi tubuh ialah protein $12,05 \%$, karbohidrat $34,83 \%$, dan lemak total 13,05\%, mineral (terutama fosfor, kalsium, dan besi), serta sejumlah vitamin A, B1 dan C. Komponen penting lainnya yang terdapat pada jantung pisang adalah serat pangan yang sangat bermanfaat bagi kesehatan (Kusumaningtyas, 2010).

Menurut Kusumaningtyas (2010) komposisi gizi jantung pisang per 100 gram adalah : energi $31 \mathrm{kkal}$, protein 1,26 g, lemak 0,35 g, karbohidrat $8,31 \mathrm{~g}$, kalsium $6 \mathrm{mg}$, besi 0,4 $\mathrm{mg}$, fosfor $50 \mathrm{mg}$, vitamin A 140 SI, vitamin B1 0,006 $\mathrm{mg}$, vitamin C 9 mg (Harismayanti, 2018).
Hasil penelitian dahulu ada pengaruh signifikan terhadap peningkatan ekskresi produksi ASI pada ibu sebelum konsumsi jantung pisang dengan peningkatan produksi ASI pada ibu setelah konsumsi jantung pisang batu sebesar 0,793 kali. Dengan demikian dapat dinyatakan bahwa mengkonsumsi jantung pisang batu dapat mempengaruhi produksi ASI dikarenakan adanya kandungan laktogogum yang dapat meningkatkan dan memperlancar produksi ASI terutama pada ibu yang mengalami masalah dalam produksi ASI.

\section{KESIMPULAN DAN SARAN}

Kesimpulan dari penelitian ini adalah produksi ASI sebelum Konsumsi Jantung Pisang Batu mempunyai mean 37.17, std.deviasi 4.20, dan produksi ASI terendah 30 tertinggi 45, Produksi ASI pada ibu post partum sesudah Konsumsi Jantung Pisang Batu mempunyai mean 59,55, std.deviasi 10.49 dan produksi ASI terendah 41,25 tertinggi 75,83 dan ada Pengaruh Konsumsi Jantung Pisang Batu Terhadap Produksi Air Susu Ibu pada 
Ibu Post Partum di Desa Banyutowo $p$ value sebesar $0,000<0,05$

Saran untuk penelitian selanjutnya Menambah pengetahuan mengenai penelitian yang diambil serta menerapkan teori dan pengetahuan yang sudah di dapat di metodologi penelitian, sehingga di harapkan dapat memberikan asuhan dan konseling perubahan produksi ASI sebelum diberikan manfaat konsumsi jantung pisang batu.

\section{DAFTAR PUSTAKA}

1. Astawan M. (2011). Pangan Fungsional untuk Kesehatan yang Optimal. Bogor: Fakultas Teknologi Pertanian IPB

2. Dinas Kesehatan Kabupaten Pati. (2016). Buku Pedoman Kesehatan Kabupaten Pati Tahun 2016. Pati : Dinas Kesehatan Pati

3. Fattah. (2016). Pengaruh Penambahan Bagian dan Level Jantung Pisang Terhadap Kualitas Fisik Sosis Daging Sapi. Jurnal Ilmu dan Industri Perternakan. Vol 2 (2), Desember 2016, Hal 95-110.

4. Kamariyah, N. (2014). Kondisi Psikologi Mempengaruhi Produksi ASI Ibu Menyusui di BPS Aski Pakis Sido Kumpul. Jurnal Ilmiah Kesehatan, Vol 7, No 12, Februari 2014, Hal 29-36.
5. Kemenkes Ri. (2013). Riset Kesehatan Dasar; RISKESDAS. Jakarta : Balitbang Kemenkes Ri Berdasarkan data Dinas Kesehatan Provinsi Jawa Tengah tahun 2016

6. Murtiana, T, (2011). Pengaruh Konsumsi Daun Katuk dengan Peningkatan Produksi ASI pada Ibu Menyusui di Wilayah Puskesmas Sawah Lebar Kota Bengkulu Tahun 2011. Bengkulu : Jurusan Kebidanan Politeknik Kesehatan Bengkulu

7. Sulistyoningsih, Hariyani. (2011). Gizi Untuk Kesehatan Ibu dan Anak. Yogyakarta: Graha Ilmu.

8. Wahyuni, (2012). Pengaruh Konsumsi Jantung Pisang Batu Terhadap Peningkatan Produksi ASI. Volume 15 Nomor 4 (2012). Yogyakarta: Pustaka Baru Pres.

9. Wahyuni, (2012). Pengaruh konsumsi jantung pisang batu terhadap peningkatan produksi ASI di Wilayah Kerja Puskesmas Srikuncoro Kecamatan Pondok Kelapa Bengkulu Tengah. Vol 15 (4), Oktober 2012. Bengkulu : Jurusan Kebidanan Politeknik Kesehatan Bengkulu

10. Walyani, Elizabeth Siwi, Purwoastuti, Endang. (2015). Asuhan Kebidanan Masa Nifas dan Menyusui. Yogyakarta: Pustaka baru press.

11. WHO. World Health Statistics (2015). Geneva: World Health Organization; 2015. 